\title{
An Overview of the Relationship between Total Quality Management and Employee Performance in a Selected Nigerian Company
}

\author{
Article by Omede Solomon Abdul \\ Management, Texila American University \\ E-mail:pharmabdul2005@yahoo.com
}

\begin{abstract}
The ever increasing demand of customers and the challenges of globalization put a lot of pressure on companies worldwide to adopt proven frameworks for organizational excellence. As a result, Nigerian companies today are implementing Total Quality Management (TQM) System. The objective of this study is to establish a relationship between total quality management and organizational performance using a manufacturing company in Nigeria. Twenty five (25) carefully framed questionnaires were sent out to the study population and 13 were returned in usable form. The Chi Square method of statistics was used to test the four formulated hypothesis. The findings showed a significant relationship between total quality management and organizational performance, between TQM and defect prevention and perception errors, between the success of TQM and perception of organizational members, between TQM and effective management of resistance to .change. This study recommends that organizational management provide enabling environment to implement TQM systems. The study concludes that a major strategy for achieving high quality is TQM with a good management system for continuous improvements that rely heavily on employee involvement.
\end{abstract}

Keywords: Defect Prevention, Globalization, Organizational Challenges, Organizational Performance and Total Quality Management.

\section{Introduction}

\section{Background}

Total Quality Management (TQM) is a business management strategy aimed at building an awareness of quality in all the organizational processes. It has been widely used in the manufacturing and service industries (Wikipedia, 2009). It is a management approach centred on quality, based on the participation of all team members and aimed at long term success through customer satisfaction. It involves making constant effort to identify customer needs and working out a strategy to cater for them. TQM is based on a culture of continuous improvement as a by-product of continuous learning and adaptation to changes in consumer demand or operational methods. TQM requires that organizations maintain quality standard in all aspects of its business by insisting that things are done right the first time and that defects/wastes are totally removed from operations. Modern business environment demands that managers plan strategically to maintain a competitive edge. Management experts have noted severally that although TQM should result in high quality products/services it sometimes does not due to improper planning, lack of a clearly defined benchmark, poor process reengineering, poor knowledge management, un- anticipated cultural change, poor process evaluation, etc.

In this particular study attempt is been made to examine the relationship if any between total quality management systems and employee performance in a Nigerian manufacturing company.

\section{Statement of the problem}

Many organizations implementing TQM in Nigeria do not appreciate the need to involve the employees at the planning stages. Consequently these companies do not derive full benefits from implementing the TQM system as employees in most cases do not clearly understand the details of the processes. This study therefore attempts to seek an answer to the question; "How could the management in a Nigerian organization implementing TQM maximize the roles of the employees so that the framework can deliver the best outcomes?" 


\section{Purpose of study}

Implementing TQM successfully requires that top management, who plans, controls, directs and implements the system should have a good knowledge of it and must properly involve the employees at the planning stages. This will enable all stakeholders to be committed to the goals of the TQM.

The objectives of this study therefore include:

1. Assessing the effectiveness of Total Quality Management as a planned competitive approach to increasing organization performance in Nigeria.

2. Assessing the extent of involvement of employees in the planning and successful implementation of the TQM process in a Nigerian company.

3. Outlines key aspects of implementation of organizational change which may enable the employee to more thoroughly and successfully participate in TQM processes in selected Nigerian company.

4. Identification of areas that needs improvement so that Nigerian companies can take better advantage of the strategic decisions involved in implementing TQM.

\section{Research questions}

The following research questions were raised:-

1. Is there a significant relationship between total quality management and organizational performance?

2. Is there a significant relationship between TQM and defect prevention or defect detection errors?

3. Is there a significant relationship between the success of TQM and perception of organization members?

4. Does employee involvement at the planning stages really matter in TQM processes?

\section{Relevance of study}

With the increasing trend in globalization, a number of Nigerian companies are seeking certification of their quality management system.

It has therefore become more expedient that company management understand better the requirements of TQM and the best practices in its implementation.

This study is therefore relevant in the following areas;

-Identification of areas of weakness in the implementation of TQM in Nigerian companies

-Identification of ideas that will promote a better understanding and implementation of TQM.

- Generating a basis for further study of issues related to total quality management amongst others.

\section{Scope of study}

This study has been limited by time and resources. Consequently the study is limited to, (a) the issue of impact of TQM on a Nigerian company. (b) Level of employee involvement in TQM processes. (c) Commitment of top management to TQM in Nigeria. (d) Communication of the benefit of quality to employees in a manufacturing firm.

\section{Literature review}

\section{The concept of total quality management (TQM)}

Total Quality Management (TQM) is a strategy that embodies the belief that the management process must focus on integrating the customer - driven quality throughout an organization (Stah, 2002). TQM stresses continuous improvement of product quality and service delivery while taking into cognizance the reality that in order to achieve this goal, employee relations needs to be equally addressed, as the customer cannot get the satisfactory service delivery from ill-motivated employees (Lewis, 2004). Chaudron (2008) asserts that for substantive change to occur, there must be changes in organization's political system, decision making processes and power bases. Carter (2003) asserts that TQM is a preventive, proactive approach to doing business and as such it reflects strategic leadership, common sense, data driven approaches to problem solving and decision making, employee involvement and sound management practice. Lawal (2006) suggests that TQM is $90 \%$ attitude, specifically the attitude 
of listening to customers. Choppins (2005) observed that success with TQM may stem from developing a unique TQM model which reflects the business ethics and purpose of business so that distress would be minimized to the barest minimum. Organizations with TQM strategy see their business through the eyes of their customers and clients and then measure their organization's performance against customer/client expectations (Fran, 2002).

\section{Expectations of total quality management (TQM)}

A decentralization of decision making responsibility to well-trained problem solving labour force, that is, it provides an avenue for the employees of an organization to participate in decision making about how the business operates and this can further improve relationships, develop trust and confidence as well as facilitate co-operative activity (Druker 2008). A combined emphasis on both incremental continuous total quality improvement and break through strategies, because TQM as a strategy encourages the employees to improve operating effectiveness as employees work in a common direction and thus, foster a change in management style and culture (Fullan, 2003). A linkage of reward and measurement systems, both formal and informal, to support these new directions, because TQM builds in the employee the ability to solve problems to be able to align to his/her personal needs, wants and desires with that of the organization (Green et al, 2003). TQM should be goal oriented and driven by results. Employees should not be allowed to perceive TQM as a top management issue that is only concerned about product quality and customer taste.

\section{The role of employees in implementing TQM strategies in organizations}

People can be better managed to embrace TQM by institutionalizing TQM organizational culture in the employees, so as to be able to deliver quality products and services to customers, Collinson et al (2003). Making adequate use of quality improvement teams and empowering employees to solve quality-related issues using such tools as AMO (Ability, Motivation \& Opportunity) as exemplified in the work of Purcell et al (2003) can serve as a leverage for the administration of a TQM system. Better feeling of job security was key element in encouraging acceptance of quality initiatives.

Another salient issue is effective communication with the employees, which is buttressed by the views of Machin J. L. J. (1980) with regards to the development of a communication improvement programme that enables top managers to work at the improvement of their own communication. This programme enables top managers to be able to deal with the complexities of the communication channels in the workplace. Closely related to communication is the need to have a well-defined organisational chart. They are useful in defining lines of controls and responsibility which is a useful input in the total quality planning process.

\section{Implementation of TQM principles and processes}

The first step in TQM implementation is to assess the organization's current reality on performance. Essential areas to look at include both micro and macro environments. The former has to do with the internal environment while the latter is the external environment. Internally you look at the leadership and employees level of readiness, their capacities and mental state. Externally you look at the standards and competitor activities. The perceptions and attitudes

It is evident from this review that employees of organizations are the most important variable in implementing a total quality management system, as they anchor procedures needed in actualizing the goal of meeting customers' requirements, consistently.

\section{Research methodology and design}

\section{Introduction}

This chapter discusses the procedures and strategies employed by the researcher to carry out the study. It consists of the samples and sampling techniques and method of analysis.

This study has used an evaluation type approach with the objective to ascertain how well a company perform in the measured variables. The sample population are employees of a company in Nigeria that is implementing Total Quality Management System. 
The research variable include knowledge of TQM, role of employees in TQM implementation and top management commitment to TQM processes.

\section{The study sample}

The study was carried out in two parts: the first being an observation of top managers in the organization with emphasis on how they respond to instructions on best practices in implementing change. The second phase involves the administration of a questionnaire to a convenience/accidental sample of top managers/employees in the selected companies (Appendix 1). The subjects were chosen based on availability. The sampling was based on readiness to give response within the very short time available to obtain the feedback.

\section{Research instrument}

A questionnaire was used to collect information for the study. The questionnaire was structured into three sections:

Section A: Personal and Company data: was designed to capture respondents' personal data with respect to current job title, years of experience as employee, number of Quality Management System training attended and the providers of such training. Questions 1-6 of this Section were designed to capture direct responses; Questions 7-8 were objective type (multiple choices) test while Question 9 was a Yes or No type.

Section B: General knowledge of TQM:- Was designed to capture respondent's source of information regarding TQM and uses a simple short essay to determine respondents' understanding of the reason why their company's top management decided to implement TQM.

In Section C: Evaluation of roles, respondents were asked to evaluate their collective roles as managers/employees in implementing TQM using a Likert 5-point measurement system. The items in this section seek to evaluate the notion and perception of respondents of their organization in following areas:

1. Ensuring that the actions necessary to achieve planned results and the continual improvement of the company's processes are implemented

2. Ensuring that documents used in our quality system are controlled

3. Contributions toward the definition of the quality policy

4. Total Quality Management policy communication to employees

5. Top management commitment to the TQM implementation process

6. Line management equal commitment to TQM implementation

7. Measurement of customer satisfaction in the last one year

8. How the company's internal structure affects the way the quality management system operates

9. Provision of resources needed to implement the Total Quality Management System

10. Removal of factors that tend to de-motivate employee in the work place

11. How the organization is structured

12. Evaluation of the effectiveness of the actions taken to develop personnel competence

13. Provision of training after a training needs assessment has been done

14. Improvement of product planning process after TQM implementation began

15. Development of competency in the use of statistical techniques in the monitoring, measurement, analysis and improvement of products and processes

Subjects were required to indicate how they perceived their collective roles as managers/employees implementing TQM. They were to score each criteria using a range of 1-5, where a score of 1 meant, very poor, a Score of 2 as being poor, a score of 3 as being fair and a score of 4 as good while 5 indicated very good. 


\section{Sources of data}

The data for this work was collected, from questionnaires administered to managers/employees in a selected manufacturing firm in Lagos, Nigeria. The company has been certified for conformance to ISO 9001 and has been implementing TQM systems for more than two years.

\section{Data collection}

The researcher, through conscious and concerted efforts, personally distributed the questionnaires by hand to the employees. The responses were obtained as soon as they were completed in the researcher's presence. Any clarification was provided by the researcher.

\section{Test of Validity}

To ensure content validity of the instrument, items capable of measuring the different variables were drawn in line with the research questions. The contents of the questionnaires were discussed with a sample of the respondents to ascertain relevance and adequacy.

\section{Methods of data analysis}

Items on the questionnaire were structured in three different forms. Responses to Questions 4-9 of Section A were analysed qualitatively using simple statistics as mean percentages. Also Questions 1 and 2 of Section D was analysed qualitatively using simple statistics as, mean percentages. Items on Section C were structured on the Likert method of five alternatives, Poor (1), Fair (2), Good (3), Very Good (4) and Excellent (5).

The respondents were asked to indicate their suitable alternatives from the five-point scale. The questions were evaluation-rating type.

The mean rating for each item was analysed as the rating for the employees in the firm for the particular criteria.

The only constraint encountered in data collection was the difficulty in reaching some employees at the time of administering the questionnaire.

\section{Analysis, interpretation and discussion of findings \\ Introduction}

This chapter presents the analysis of the data obtained from the questionnaire administered on the respondents. Each questionnaire was randomly numbered since the names of the respondents were not captured. In all responses from 13 subjects were used in the study.

The following tables represent the responses to the questionnaire

\section{Measure of TQM information}

Table 1. Source-field study

\begin{tabular}{|l|l|l|}
\hline Source of information & No of listing & Percentage \\
\hline Training ins attendance & 5 & 38.46 \\
\hline Internet websites & 2 & 15.38 \\
\hline Reading books and journals & 2 & 15.38 \\
\hline Newspapers and other mass media & 1 & 7.69 \\
\hline $\begin{array}{l}\text { Interactions with management and } \\
\text { colleagues }\end{array}$ & 1 & 7.69 \\
\hline System documentation & 1 & 7.69 \\
\hline TQM Standard -Requirements & 1 & 7.69 \\
\hline
\end{tabular}

Though an organization may engage a consultant in its bid to implement TQM, there are yet various sources of useful information on TQM. This information could go a long way in expanding the benefits that a firm could derive from the implementation of the standard.

From Table 1, it is clear that training provides the commonest source of information $(38.48 \%)$, Internet websites $(15.38 \%)$, books and journals (15.38\%), newspapers (7.69\%), interactions with 
management and colleagues (7.69\%), System documentation (7.69\%) and the ISO 9001 standard $(6.69 \%)$.

The role of training is once again highlighted by the trend. The impact of emerging technology especially the Internet is noted. Incidentally, the subjects from this firm which has a high number of years in TQM implementation were actively engaged in the use of Internet as well as reading of appropriate books and journal in sourcing information on Quality Management System.

Newspapers and other media accounted for $7.69 \%$, which is remarkable especially since the media is primarily dedicated to news and information that may not offer technical advantage. The use of newspapers was more common among managers.

Interestedly, $7.69 \%$ of the respondents use the standard as a source of information on the requirements of TQM. The inference is that many managers may not have a global picture of the standard's requirement and consequently may not be totally committed and dedicated to those processes they own.

\section{Reasons for implementing TQM}

Table 2. Respondents understanding of the reasons companies implement TQM

\begin{tabular}{|l|l|l|}
\hline Reasons for implementing TQM & $\begin{array}{l}\text { No of } \\
\text { listing }\end{array}$ & Percentage \\
\hline $\begin{array}{l}\text { Marketing purposes-to enhance sales/ improve } \\
\text { customers perception }\end{array}$ & 6 & 46.2 \\
\hline Improve Productivity & 5 & 38.5 \\
\hline Standardization of processes and procedures & 2 & 15.3 \\
\hline & $\mathbf{1 3}$ & $\mathbf{1 0 0 . 0}$ \\
\hline
\end{tabular}

The main reason companies implement a Quality Management System such as TQM is to ensure that every time a process is performed the same information, methods, skills and controls are used and applied in a consistent manner. This normally will deliver products and services that meet customers' requirement. Every other derivable from implementation of TQM systems must be seen to emanate from having systems that deliver the right products and services.

From Table 2, a large number (46.2\%) of the subjects said companies implement TQM for marketing related purposes - increasing sales and customer's appeal. While making good products and services will ultimately increase sale it is important to note that the emphasis is on the system that delivers the product. From practice, the researcher has experience situation where firms paying consultant fess to facilitate their TQM certification process are unable to provide basic resources that will facilitate product delivery. Only $15 \%$ of the respondents have a clear understanding of the reason companies implement TQM.

\section{Evaluation of employees' role in companies implementing TQM}

The managers rating of how well certain criteria are implemented is used as a basis of evaluating their roles on a Likert-5 point's scale. The perceptions of the 13 subjects' are as shown below:

Table 3. Managers/Employees evaluation of performance on certain criteria

\begin{tabular}{|l|l|l|l|l|l|l|l|}
\hline S/N & Particulars & $\mathbf{1}$ & $\mathbf{2}$ & $\mathbf{3}$ & $\mathbf{4}$ & $\mathbf{5}$ & $\mathbf{A V}$ \\
\hline 1. & $\begin{array}{l}\text { How well we have ensured that the } \\
\text { actions necessary to achieve planned } \\
\text { results and the continual improvement of } \\
\text { the company's processes are implemented }\end{array}$ & 0 & 0 & 0 & 6 & 7 & 5 \\
\hline 2. & $\begin{array}{l}\text { How well we have ensured that } \\
\text { documents used in our quality system are } \\
\text { controlled }\end{array}$ & 0 & 0 & 0 & 5 & 8 & 5 \\
\hline 3. & $\begin{array}{l}\text { How well we have contributed towards } \\
\text { the definition of the quality policy }\end{array}$ & 0 & 0 & 0 & 5 & 8 & 5 \\
\hline
\end{tabular}




\begin{tabular}{|c|c|c|c|c|c|c|c|}
\hline 4. & $\begin{array}{l}\text { How well our quality policy has been } \\
\text { communicated to employees }\end{array}$ & 0 & 0 & 0 & 8 & 5 & 4 \\
\hline 5. & $\begin{array}{l}\text { How well our top management is } \\
\text { committed to the implementation process }\end{array}$ & 0 & 0 & 0 & 8 & 5 & 4 \\
\hline 6. & $\begin{array}{l}\text { How well the management team show } \\
\text { equal commitment to TQM } \\
\text { implementation }\end{array}$ & 0 & 0 & 0 & 8 & 5 & 4 \\
\hline 7. & $\begin{array}{l}\text { How well we have been involved in } \\
\text { performing customer satisfaction survey } \\
\text { in the last one year }\end{array}$ & 0 & 0 & 3 & 9 & 1 & 4 \\
\hline 8. & $\begin{array}{l}\text { How well our internal structure has } \\
\text { affected the way we run our quality } \\
\text { management system }\end{array}$ & 0 & 0 & 1 & 11 & 1 & 4 \\
\hline 9. & $\begin{array}{l}\text { How well we provided resources needed } \\
\text { to implement the Quality Management } \\
\text { System }\end{array}$ & 0 & 0 & 0 & 11 & 2 & 4 \\
\hline 10. & $\begin{array}{l}\text { How well we have removed all factors } \\
\text { that tend to de-motivate staff in the work } \\
\text { place }\end{array}$ & 0 & 0 & 2 & 7 & 4 & 4 \\
\hline 11. & $\begin{array}{l}\text { How well we have defined our } \\
\text { organizational structure }\end{array}$ & 0 & 0 & 3 & 10 & 0 & 4 \\
\hline 12. & $\begin{array}{l}\text { How well we provide trainings after a } \\
\text { training needs assessment has been done }\end{array}$ & 0 & 0 & 2 & 11 & 0 & 4 \\
\hline 13. & $\begin{array}{l}\text { How well training received impacted on } \\
\text { your ability to meet customers' } \\
\text { requirements }\end{array}$ & 0 & 0 & 3 & 10 & 0 & 4 \\
\hline 14. & $\begin{array}{l}\text { How well we have improved our product } \\
\text { planning process since we began TQM } \\
\text { implementation }\end{array}$ & 0 & 0 & 3 & 9 & 1 & 4 \\
\hline 15. & $\begin{array}{l}\text { How well we have developed competency } \\
\text { in the use of statistical techniques in the } \\
\text { monitoring, measurement, analysis and } \\
\text { improvement of products and processes }\end{array}$ & 0 & 0 & 3 & 7 & 2 & 4 \\
\hline
\end{tabular}

From Table 3, it is evident implementing TQM helps an organization to set up the actions necessary to achieve planned results and the continual improvement of the company's processes which are critical to meeting customers requirement.

The managers are also effective communicating the quality policy and other quality programmes. Essentially, they were involved in establishing the quality policies.

Areas of weakness were not easily discerned because of the statistics used. The researcher has not compared the differences in scores because of the duration of TQM implementation. It would also be interesting to compare scores of managers in these criteria against those who are working in organizations not implementing TQM.

\section{Summary, conclusions and recommendations}

\section{Summary of findings}

From the findings of this study it can be appreciated that companies that implement TQM are able to improve their processes by defining a quality policy and getting it communicated to employees. As part of the implementation process companies engage consultants and these professionals are major providers of Quality Management System training in addition to facilitating the development of documents amongst others.

Training was found to help in developing competencies to run processes and procedures that deliver customer's needs, but incidentally, the number of trainings attended was not a function of how long an 
employee had been a manager. In such instances employees who had worked in other firms implementing TQM had attended more TQM training than more experienced managers in the companies under study.

Apart from training, Internet search and the reading of books and journals provides the highest means of obtaining information on Quality Management System implementation. Unfortunately, only a few managers actually bother to read the contents of the TQM standard itself.

From this work, it is also revealed that managers do not have a unified opinion of the reason why companies implement TQM. The benefits derivable from enhanced perception at the marketplace seem to be widely accepted as reasons for implementing TQM.

In rating the manager roles collectively, areas of strength include setting up the system and communicating policies to employees. Areas of weakness include not been able to sufficiently remove factors that de-motivates employees and low level in the use of statistical techniques.

In all, Nigerian managers are on track in their roles in implementing TQM but could further maximise the benefits their companies get by increasing their working knowledge of the standard and striving to obtain total ownership of the system by the management team and employees alike. It is also necessary that managers learn to use statistical tools in improving their process and products quality.

\section{Implications for further research}

The researcher believes that this study has some tremendous implications.

These include the following:

Firstly, it sets a basis for interest for other researchers to work on how quality management systems work in Nigeria. A particular research thought could be the Nigeria factor in the certification process. It also provides an opportunity to research on how top management commitment to TQM approaches as many companies line in for certification.

Secondly, it provides opportunity for curriculum planners in tertiary institutions to develop new professional courses in Quality Management Systems as operates in many developed nations.

\section{Conclusions}

The data collected, collated, analysed and interpreted showed that implementing TQM is a good strategic decision, but it should be taken for what it is - creating a system that delivers products and services that meet customers' needs through employee performance.

Managers/employees in Nigerian companies must enhance their knowledge of the concept and principle involved in Total Quality Management System. This could be done by reading appropriate textbooks and journals as well as taking advantage of the opportunities available on the Internet. The right training should be identified, developed and conducted for all managers and employees.

\section{Recommendation}

The researcher makes the following recommendation based on the outcome of this work and experience gained in the field helping organization develop TQM.

1. Managers should seek further training and education on Total Quality Management

2. Top management of Nigeria companies should begin to see the real reason for TQM implementation and thus provide the required resources to develop the their quality management system

3. Managers should remove all factors that de-motivates employees so that their systems could work better

4. Educational institutions should develop new courses in Total Quality Management System to help develop local manpower necessary for national development

\section{Suggestion for further research}

This work has been based on a firm in Nigeria, with about 146 companies already certified in the country, opportunities for further research is evident in the following areas:

1. Measurement of contribution derived from certification of companies

2. Evaluation of the role of consultants in the TQM implementation process 
3. The extent of developing systems that are ready for additional intervention e.g., introduction off Total Quality Management, Six-sigma and Excellence -Models (Malcolm Baldbrige Quality Awards, Deming Prize etc.)

\section{Acknowledgment}

In writing this capstone project I have had to recount my experiences with Sylvia Subhashiini, Preetha and Kaushika, while contemplating on enrolling for the program and my late friend, Mr. Cletus Musa with whom I kept on discussing the need to obtain a $\mathrm{PhD}$ and have it written as part of our epitaph. I remain very grateful too to my wife, Mrs. Maliyatu Omede and senior brother, Mr. Stephen Omede for their unending support. And to the Holy Trinity, for the spiritual guidance.

\section{References}

[1]. Akinola, C. (1999): Office Administration for Managers and Secretaries Lagos Vision-Plus Ventures.

[2]. Boiral, O (1996): ISO 9000: Outside the Iron Cage in www.daesgisq.com.

[3]. Dale, B \& Bunny, H. (1999) Total Quality Management Blueprints, Oxford, Blackwell Publishers Limited

[4]. Hoyle, D, \& Thompson, J. (2001) Converting a Quality Management System using the Process Approach United Kingdom, Transition Support Limited.

[5]. Hoyle, D. (2001): ISO 9000 Quality Systems Handbook London, Butterworth-Heinemann.

[6]. Machin J. L. J. (1980): The Expectations Approach- Improving managerial communication and performance London, McGraw-Hill Book Company (U K) Limited.

[7]. Martin, W. B. (1989): Managing Quality Customer Service London, Kogan Page Ltd.;

[8]. Naumann, E. \& Hoistington, S, (2001): Customer Centered Six Sigma - Linking Customers, Process Improvement, and Financial Results, Wiscosin, American Society for Quality Press.

[9]. O'Hanlon, T, (2002): Quality Audits for ISO 9001:2000: Making compliance value-added Wisconsin, Quality Press.

[10]. Okolie, E. E. (2002): Upgrading Your Quality System to ISO 9000 Standards- A practical Approach Ibadan, Spectrum Books Limited.

[11]. Onwuka W. E. (2006): Implementing ISO 9001:2000 An unpublished training document

[12]. Onyene, V. E. (2000): Dynamics of Institutional Management -Towards Strategic Administrative Competence Lagos; Sam Orient Publishers.

[13]. Pasterczyk, C. E (1999): A Graded Approach to ISO 9000 Implementation for Records Managers in www.sandia.gov/html.

[14]. Peters, T. (1995): In search of Excellence, New York, Harper Collins.

[15]. Simmons, B. L. \&White, M. A. (1999): "The Relationship between ISO 9000 and Business Performance: Does Registration Really Matter?” Journal of Managerial Issues, Vol. 11, 1999.

[16]. Sprow; E. (1992): Insights into ISO 9000” Manufacturing Engineering, p 73, September 1992.

[17]. Standards Organisation of Nigeria. SON Import/Export Inspection Guidelines, Lagos.

[18]. Togun, A. (2005): Business Policy for Graduates and Professionals, An instruction manual for LAUTECH MBA programme, Ogbomoso.

[19]. Waller, J., Allen, D., \& Burns, A. (1993) The Quality Management Manual- How to write and develop a successful manual for Quality Management System, London, Kogan Page Limited.

[20]. Wilkins, R. H. (1994): The Quality Empowered Business: Creating a circle-4 Quality System for Success, New Jersey, Prentice Hall, Inc. 